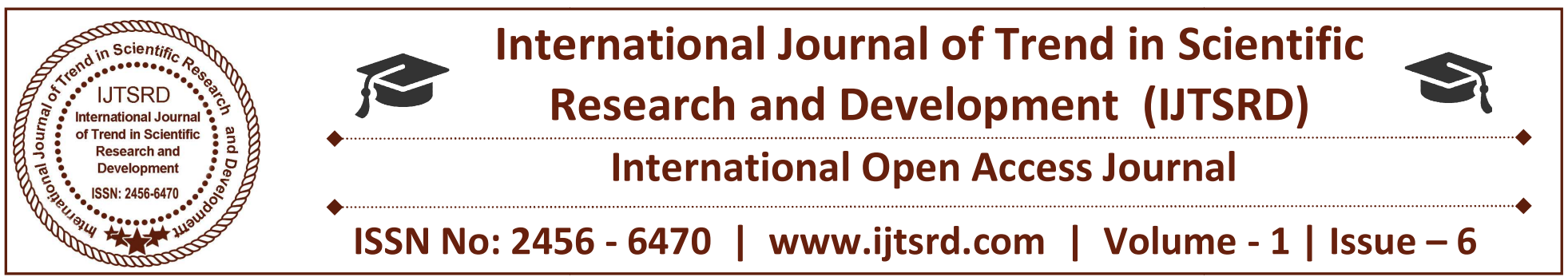

\title{
A Research on Enumerating the Customer Satisfaction Regarding Online Shopping
}

\author{
Kankipati Ajay Kumar \\ M.B.A., M.Com.,(Ph.D), Research Scholar at \\ K L University \& Assistant Professor at \\ PACE Institute of Technology and Sciences, \\ Department of Management Ongole, Prakasam
}

\author{
Suresh Chakka \\ M.B.A., (Ph.D), Assistant Professor at \\ PACE Institute of Technology and Sciences, \\ Department of Management, Ongole, Prakasam
}

\begin{abstract}
Online shopping has become a very popular shopping routine ever since the internet has declared a takeover. There are many individuals who are looking for other amazing alternatives for shopping and this online shopping is just the fix for that. There are many advantages of online shopping. This is the reason why individual's opted online stores and these are booming business today. Online shopping includes buying clothes, gadgets, regular shoes, appliances, or even daily groceries. Now a days people are habituated for making purchase through all this online shopping websites. Currently it has become one of the popular approaches for business and customer to perform trade over the internet. Businesses have been coming up with creative ways to promote their product via online. Thus it describes how modern market is replacing the traditional markets. This study is taking place to identify the factors that may influence customer's online shopping satisfaction. Generally, the success of online shopping essentially depends on the customer satisfaction during their purchase.
\end{abstract}

Keywords: Customer Satisfaction, Online shopping, factors of purchase.

\section{Introduction:}

Online shopping is the process whereby consumers choose to buy goods, services through online etc. from a seller interactively on real-time without an intermediary service over the internet. Online shopping, it is the process of buying goods and services from merchants who sell on the Internet. the emergence of the World Wide Web, merchants have sought to sell their products to people who uses the Internet. Shoppers can visit web stores from their convenient places of their homes and shop as they sit in front of the computer. Consumers buy a variety of items from online stores.

Recent days, E-commerce is a fast growing phenomenon. Increase in numbers of consumers shop online to purchase goods and services, gather product information or even browse for enjoyment. Online shopping environment are therefore playing an increasing role in the overall relationship between markets and their consumers. That is, consumerpurchases are mainly based on the cyberspace appearance such as pictures, image, quality information, and video clips of the product, not on the actual experience. As the internet has now become a truly global phenomenon, the number of internet users worldwide is expected to reach 1.8 billion by 2010 according to the survey of stats, this growing and diverse internet population means the people having diverse taste and purposes are now going to web for information and to buy products and services.

The wide use of internet and the rapid growth of technology have created a new market for both the customers and business. Now a days internet is not just another medium to get in touch with customers, but it is an important channel to find potential customers as well as channel to continue relationship with existing customers. 
Essentially, the idea of online shopping is to lead customers to a convenient way of shopping. Customers will be able to save their time and money, plus retrieve all the product information with just few clicks in few minutes. Plus, purchasing can be done anywhere, anytime according to their preferences.

\section{Statement of Problem:}

The problem area of this survey is consumer's satisfaction and attitudes towards online shopping will determine the factors that influence customers to shop online and those factors will help the marketers to formulate their strategies towards online marketing.

\section{Review of the Literature}

Kiran Ghosal analysed that Overall shopping experience was very good except for the inconvenience of seeing a lot of items that are not in stock. Think they have added a lot of products in to their database just to give a feeling that they have a big catalog but it will make anyone frustrated to see so many items in the catalog and later figure out most of them are not in stock.

Peter discussed before but started hearing about the same in last few months had visited the site and the first impression was not bad. It was excited by seeing a lot of items at a decent price. A search for Tripod showed over 25 items, starting from a price range of Rs 250 to Rs 10,000. Then short listed a couple of them and started reading reviews. However, It was eventually figured out they have just one model in stock, which is over $17000 \mathrm{INR}$, which was beyond my budget.

Rohan Analysed 'Indian online shoppers believed there was a wider purchase choice online rather than offline, that shopping online was extremely convenient and easy, and that most goods were cheaper online than they were offline,' says, Country Manager, West Africa, MasterCard Worldwide.

Business Standard also explored the reasons why the majorities (67\%) of Indians surveyed do not currently shop online. Of this group, $49 \%$ said they were not sure that making transactions online was secure or safe, $33 \%$ said they simply preferred to shop in -store to look at the physical products and an additional $30 \%$ raised their concerns about the time it would take for items to be delivered to them.

Krishnan Pandey Online security is a priority for and we work closely with our customer financial institutions and retailers in Nigeria to ensure that online holders can have the highest level of confidence when shopping online, and that retailers can gain greater assurance about the identity of the customer completing a purchase.

\section{Objectives of the Study}

$>$ To enumerate the satisfaction level of the customer for E-commerce.

$>$ To know the specific reasons for purchase at online.

To find out the satisfaction levels of customers for services provided by the online shopping.

\section{Scope of the Study}

$>$ To find out about which type of products people prefer most.

$>$ To know the reasons for the buying e-commerce products.

$>$ To extract the price range that people prefer most.

$>$ To know which features they admire in their product

\section{Limitations of the Study}

$>$ The study is confined to Ongole and Guntur cities only

$>$ The study is based upon the consumer preferences of online shopping

$>$ The data collected for the research is fully on primary data given by the respondents. There is chance for personal bias. So the accuracy is not true

\section{Research Methodology}

The research design used for the study . The research design used for the study is descriptive. Descriptive research studies are those, which are concerned with describing the characteristics of a particular individual or group. The studies concerned with specific prediction with narration of facts and characteristics concerning individual group or situation are all examples of descriptive research studies.

\section{Population Size}

All the users of internet who are surfing online shopping sites in Guntur and Ongole cities. There were more than 2 Lakhs highly educated and users of internet were there in both the cities

\section{Sample Size}

It is not possible to do research based on total population in both the cities, because of money and time constraints, that's why researcher took 200 respondents as a sample to do research. So the sample 
size 200, which comprises of 100 respondents from Guntur and 100 Respondents from Ongole City.

\section{Sample Design}

Researcher took Cluster Sampling to do the research, as the name indicates we divided the population into several clusters and finally took the sample from that.

\section{Statistical Tools}

Ranking analysis and average percentage analysis techniques are being used to do conduct the research.

\section{Data Analysis and Interpretation}

Table 1: Gender Parameter of the respondents

\begin{tabular}{|c|c|c|c|}
\hline $\begin{array}{c}\text { S. } \\
\text { No }\end{array}$ & Gender & $\begin{array}{c}\text { No of. } \\
\text { Respondents }\end{array}$ & Percentage \\
\hline 1 & Male & $\mathbf{1 0 0}$ & $\mathbf{5 0 \%}$ \\
\hline 2 & Female & $\mathbf{1 0 0}$ & $\mathbf{5 0 \%}$ \\
\hline & & $\mathbf{2 0 0}$ & $\mathbf{1 0 0 \%}$ \\
\hline
\end{tabular}

\section{Interpretation}

From the above table 1 reveals that $50 \%$ of the respondents are male and $50 \%$ of the respondents are female

Table 2: Age Parameter of the respondents

\begin{tabular}{|c|c|c|c|}
\hline S.No & Age & $\begin{array}{c}\text { No of } \\
\text { Respondents }\end{array}$ & Percentage \\
\hline 1 & Below 18 & $\mathbf{9 0}$ & $\mathbf{4 5 \%}$ \\
\hline 2 & $\mathbf{1 9 - 2 5}$ & $\mathbf{5 0}$ & $\mathbf{2 5 \%}$ \\
\hline 3 & $\mathbf{2 5 - 4 0}$ & $\mathbf{3 5}$ & $\mathbf{1 7 . 5 \%}$ \\
\hline 4 & More Than 40 & $\mathbf{2 5}$ & $\mathbf{1 2 . 5 \%}$ \\
\hline & & $\mathbf{2 0 0}$ & $\mathbf{1 0 0 \%}$ \\
\hline
\end{tabular}

\section{Interpretation}

From the above table 2 reveals that $45 \%$ of the respondents are below 18 and $12.5 \%$ of the respondents are more than 40 .

Table 3: Location Parameter of the respondents

\begin{tabular}{|c|c|c|c|}
\hline S.No & Location & $\begin{array}{c}\text { No. of } \\
\text { Respondents }\end{array}$ & Percentage \\
\hline 1 & Rural & $\mathbf{1 0}$ & $\mathbf{5 \%}$ \\
\hline 2 & Semi-Urban & $\mathbf{2 0}$ & $\mathbf{1 0 \%}$ \\
\hline 3 & Urban & $\mathbf{1 7 0}$ & $\mathbf{8 5 \%}$ \\
\hline & & $\mathbf{2 0 0}$ & $\mathbf{1 0 0 \%}$ \\
\hline
\end{tabular}

\section{Interpretation}

From the above table 3 reveals that $85 \%$ of the respondents are from urban Area and $5 \%$ of the respondents are from rural background.

Table 4: Monthly Income Parameter of the respondents

\begin{tabular}{|c|c|c|c|}
\hline S.No & Income & $\begin{array}{c}\text { No. of } \\
\text { Respondents }\end{array}$ & Percentage \\
\hline 1 & $\begin{array}{c}\text { Below } \\
10000\end{array}$ & 30 & $15 \%$ \\
\hline 2 & $\begin{array}{c}10001- \\
25000\end{array}$ & 120 & $60 \%$ \\
\hline 3 & $\begin{array}{c}25001- \\
50000\end{array}$ & 35 & $17.5 \%$ \\
\hline 4 & $\begin{array}{c}\text { More Than } \\
50000\end{array}$ & 25 & $12.5 \%$ \\
\hline & & 200 & $100 \%$ \\
\hline
\end{tabular}

\section{Interpretation}

From the above table 4 reveals that $60 \%$ of the respondents are from $10001-25000$ per month and $12.5 \%$ of the respondents are belongs to more than 50000 .

Table 5: Online shopping websites visited Parameter of the respondents

\begin{tabular}{|c|c|c|c|}
\hline $\begin{array}{c}\text { S. } \\
\text { No }\end{array}$ & Websites & $\begin{array}{c}\text { No. of } \\
\text { Respondents }\end{array}$ & Percentage \\
\hline 1 & Flipkart & 70 & $35 \%$ \\
\hline 2 & Amazon & 55 & $27.5 \%$ \\
\hline 3 & Snapdeal & 30 & $15 \%$ \\
\hline 4 & Shopclues & 10 & $5 \%$ \\
\hline 5 & Myntra & 20 & $10 \%$ \\
\hline 6 & Ebay & 15 & $7.5 \%$ \\
\hline & & 200 & $100 \%$ \\
\hline
\end{tabular}

\section{Interpretation}

From the above table 5 Online shopping websites visited Parameter of the respondents reveals that $35 \%$ of the respondents are visiting flipkart and $27.5 \%$ of the respondents are visiting amazon and 5\% are visiting shopclues 
Table 6: Products Purchased Parameter of the respondents

\begin{tabular}{|c|c|c|c|}
\hline S.No & $\begin{array}{c}\text { Products Purchased } \\
\text { By The Respondents }\end{array}$ & $\begin{array}{c}\text { No. Of } \\
\text { Respondents }\end{array}$ & Percentage \\
\hline 1 & Electronics & $\mathbf{5 5}$ & $\mathbf{2 7 . 5 \%}$ \\
\hline $\mathbf{2}$ & Mobiles & $\mathbf{4 0}$ & $\mathbf{2 0 \%}$ \\
\hline $\mathbf{3}$ & Computers & $\mathbf{2 5}$ & $\mathbf{1 2 . 5 \%}$ \\
\hline $\mathbf{4}$ & Home Appliances & $\mathbf{2 0}$ & $\mathbf{1 0 \%}$ \\
\hline $\mathbf{5}$ & Games & $\mathbf{1 5}$ & $\mathbf{7 . 5 \%}$ \\
\hline $\mathbf{6}$ & Garments & $\mathbf{1 5}$ & $\mathbf{7 . 5 \%}$ \\
\hline 7 & Women Accessories & $\mathbf{1 5}$ & $\mathbf{5 \%}$ \\
\hline $\mathbf{8}$ & Men Accessories & $\mathbf{1 0}$ & $\mathbf{2 . 5 \%}$ \\
\hline $\mathbf{9}$ & Books & $\mathbf{5}$ & $\mathbf{1 0 0 \%}$ \\
\hline & & $\mathbf{2 0 0}$ & \\
\hline
\end{tabular}

\section{Interpretation}

From the above table 6 Products Purchased Parameter of the respondents reveals that $27.5 \%$ of the respondents are purchasing electronics and $2.5 \%$ of the respondents are purchasing books

Table 7: Preferences Parameter of the respondents

\begin{tabular}{|c|c|c|c|}
\hline S.No & Preferences & No.Of.Respondents & Percentage \\
\hline 1 & Clear Information & $\mathbf{2 5}$ & $\mathbf{1 2 . 5 \%}$ \\
\hline 2 & Time Saving & $\mathbf{4 0}$ & $\mathbf{2 0 \%}$ \\
\hline 3 & Less Expensive & $\mathbf{3 0}$ & $\mathbf{1 5 \%}$ \\
\hline 4 & Good Offers & $\mathbf{5 5}$ & $\mathbf{2 7 . 5 \%}$ \\
\hline 5 & Service Quality & $\mathbf{3 0}$ & $\mathbf{1 5 \%}$ \\
\hline 6 & Delivery Speed & $\mathbf{2 0}$ & $\mathbf{1 0 \%}$ \\
\hline & & $\mathbf{2 0 0}$ & $\mathbf{1 0 0 \%}$ \\
\hline
\end{tabular}

\section{Interpretation}

From the above table 7 Products Purchased Parameter of the respondents reveals that $27.5 \%$ of the respondents are purchasing because of good offers at online and 10\% of the respondents are purchasing because of Delivery Speed.

Table 8: Mode of payment Parameter of the respondents

\begin{tabular}{|c|c|c|c|}
\hline S.No & Preferences & No.Of.Respondents & Percentage \\
\hline 1 & Credit Card & $\mathbf{5 5}$ & $\mathbf{2 7 . 5 \%}$ \\
\hline 2 & Debit Card & $\mathbf{4 0}$ & $\mathbf{2 0 \%}$ \\
\hline 3 & Online Bank & $\mathbf{3 0}$ & \\
\hline 4 & Transfer & $\mathbf{4 5}$ & $\mathbf{2 2 . 5 \%}$ \\
\hline $\mathbf{5}$ & Cash On Delivery & $\mathbf{3 0}$ & $\mathbf{1 5 \%}$ \\
\hline & Wallet Payments & $\mathbf{2 0 0}$ & $\mathbf{1 0 0 \%}$ \\
\hline
\end{tabular}

\section{Interpretation}

From the above table 8 Mode of payment Parameter of the respondents reveals that $27.5 \%$ of the respondents are purchasing by using of credit cards at online and $15 \%$ of the respondents are purchasing by using of wallet payments and online bank transfer. 


\section{Findings:}

$>$ Hence it is concluded that majority $50 \%$ of the respondents are male and rest of $50 \%$ of the respondents are females.

$>$ Hence $45 \%$ of the respondents are below 18 and $12.5 \%$ of the respondents are more than 40 .

$>$ Hence that $85 \%$ of the respondents are from urban Area and $5 \%$ of the respondents are from rural background.

$>$ Hence that $60 \%$ of the respondents are from 10001 - 25000 per month and $12.5 \%$ of the respondents are belongs to more than 50000

$>$ Hence that $35 \%$ of the respondents are visiting Flipkart and $27.5 \%$ of the respondents are visiting Amazon and 5\% are visiting Shopclues

$>$ Hence that $27.5 \%$ of the respondents are purchasing electronics and $2.5 \%$ of the respondents are purchasing books

$>$ Reveals that $27.5 \%$ of the respondents are purchasing because of good offers at online and $10 \%$ of the respondents are purchasing because of Delivery Speed.

\section{Conclusion:}

Online shopping is becoming more popular day by day with the increase in the usage of online. Understanding customer's need for online selling has become challenge for marketers. Specially understanding the consumer's attitudes towards online shopping, making improvement in the factors that influence consumers to shop online and working on factors that affect consumers to shop online will help marketers to gain the competitive edge over others.

In conclusion, having access to online shopping has truly revolutionized and influenced our society as a whole. This use of technology has opened new doors and opportunities that enable for a more convenient lifestyle today. Variety, quick service and reduced prices were three significant ways in which online shopping influenced people from all over the world. However, this concept of online shopping led to the possibilities of fraud and privacy conflicts.

Unfortunately, it has shown that it is possible for criminals to manipulate the system and access personal information. Luckily, today with the latest features of technology, measures are being taken in order to stop hackers and criminals from inappropriately accessing private databases.

Through privacy and security policies, website designers are doing their best to put an end to this unethical practice. By doing so, society will continue to depend upon online shopping, which will allow it to remain a tremendous success in the future.

\section{REFERENCES:}

1) Journal of Economics, Business and Management, Vol. 2, No. 1, February 2014. The Impact of Customer Satisfaction on Online Purchasing: A Case Study Analysis in Thailand.

2) Stephen F. King en Juhn-Shiuan Liou, "A framework for internet channel evaluation", International Journal of Information \& Management. March, 24, 2004.

3) Campbell DJ. Task complexity: A review and analysis. Academy of Management Review, 13, 1, 1998.

4) "Nielsen Global Online Shopping Report". Blog.nielsen.com. 2010-06-29. Retrieved 01, 19, 2012

5) Peterson RA, Balasubramanian S, Bronnenberg BJ. Exploring the implications of the Internet for consumer marketing. Retrieved June, 28, 1997

6) Palmer, Kimberly, More Consumers Using Tablets to Holiday Shop Study". December 8, 2011. 